\title{
Using Tannery Sludge to Manage Soybean Cyst Nematodes in Soybean Crops
}

\author{
Jéssica Rodrigues de Mello ${ }^{1}$, Janaina Alves de Almeida Moreira ${ }^{1}$, Guilherme Malafaia ${ }^{1}$ \\ \& Fernando Godinho de Araújo ${ }^{1}$ \\ ${ }^{1}$ Instituto Federal Goiano Campus Urutaí, Urutaí, GO, Brazil \\ Correspondence: Rodovia Geraldo Silva do Nascimento, Instituto Federal Goiano Campus Urutaí, Urutaí, Km \\ 2.5, CEP: 75790-000, GO, Brazil. Tel: 55-64-3465-1900. E-mail: janainaalmeida.agro@gmail.com
}

Received: October 1, 2017

Accepted: November 2, $2017 \quad$ Online Published: November 15, 2017

doi:10.5539/jas.v9n12p294

URL: https://doi.org/10.5539/jas.v9n12p294

\begin{abstract}
Soybean crop (Glicyne max) is host to a range of pathogens, among them phytonematoids, with emphasis on the soybean cyst nematode (Heterodera glycines), which has recently caused great damages to the crop and compromised its productivity. Alternatives to the management of diseases, caused by phytonematoids, that are effective and less harmful to the environment, are increasingly being sought. Thus, the incorporation of organic compounds into the soil, such as tannery sludge (bovine chain by-product), presents great potential in the management of soil-borne pathogens, as well as reducing environmental impacts caused by the release into the environment. Thus, the aim of present study had as objective to evaluate the effect of different tannery sludge doses on the management of $\mathrm{H}$. glycines in greenhouse. The study used a nematode-susceptible cultivar (BRS Valiosa RR) and followed a completely randomized experimental design, with 5 repetitions. The nematode penetration in the roots was assessed 10 days after inoculation (DAI), whereas the fresh root mass, the number of females per root gram, and the number of eggs per female were assessed 30 DAI. The tannery sludge is efficient in the management of $H$. glycines in nematode-susceptible soybean cultivars, reducing the number of females per gram of root, the number of juveniles of the second stage (J2) of the nematoid per root system and promoting increases in fresh mass of the roots. However, more studies are needed to understand the dynamics of the nematode reduction in the presence of the organic compound, since nematode reproduction was not affected by the presence of tannery sludge.
\end{abstract}

Keywords: Glycine max, H. glycines, nematode management, tannery sludge, crop yield

\section{Introduction}

The nematode $H$. glycines Ichinohe (1952), also known as soybean cyst nematode (SCN), stands out among phytosanitary issues limiting the achievement of high soybean yields (Glicyne max (L.) Merril) due to the damages it causes to crops and to the easy dissemination assured by cysts (Embrapa, 2015). The SCN was first detected in Brazil in the 1991/1992 crop (Lima et al., 1992; Lordello et al., 1992; Monteiro \& Morais, 1992); since then, it has negatively affected the soybean cultivation in the country. According to Inomoto (2006), the losses caused by this nematode in sandy soils under low infestation conditions may vary from $10 \%$ to $30 \%$ and, in high incidence cases, these losses may reach $70 \%$. Once the nematode is found in the field, producers should take measures to keep the population density low in order to avoid damaging the crop of agricultural interest, since eradicating the pathogen is not possible (Dias et al., 2009).

The most used tools in the management of $H$. glycines are: resistant cultivars, due to their efficiency and economic viability (Xu, 2002); crop rotation, in order to limit the number of SCN hosts (Riggs \& Schmitt, 1993); and soil management (no-tillage, soil decompaction, soil fertility, among others) (Dhingra et al., 2009). Nematicides (chemical control) increase production costs, show low nematode control efficiency and are difficult to be applied. In addition, these products are based on aldicarb, cabofuran, oxamyl and fenamiphos, which show high toxicity degree (Steffen et al., 2011). Thus, it is necessary finding alternative control measures able to cause less damage to the environment and to human health in order to help developing a more sustainable agriculture.

Tannery sludge shows great potential to control pathogens (Bettiol \& Santos, 2008) due to its potential to incorporate organic residues in the soil in order to stimulate plant growth and nutrient supply (Costa et al., 2001; 
Araújo et al., 2008; Martines, 2009; Santos, 2010), as well as to its capacity to activate the soil microbiota and suppress soil diseases (Lumsden et al., 1983; Araújo \& Bettiol, 2005). According to some authors, the action mechanism of organic compounds results from decomposition processes, which release compounds (ammonia and fatty acids) with nematicide properties, fact that negatively affects phytonematode populations (Oka, 2010; Ferraz et al., 2010). As per Bettiol and Santos (2008), plant disease control through sludge happens through the activation of the soil microbiota, which enables natural biological control. Another plausible justification lies on the fact that the sludge increases soil $\mathrm{pH}$ (Santos, 2010) and that $\mathrm{pH}$ near alkalinity does not favor nematode development (Massaroto \& Yamashita, 2011). Different authors report that the application of organic sludge leds to satisfactory management of the nematode Meloidogyne javanica in soybean crops (Araújo \& Bettiol, 2005; Araújo \& Gentil, 2010). Renco et al. (2007) studied the effects of different organic compound sources on Globodera rostochiensis survival and reproduction in potato cultivations and found that all the tested compounds significantly reduced the number of nematode eggs and juveniles. In addition, studies showing tannery sludge efficiency against $H$. glycines remain scarce.

In this context, the aim of the present study was to assess the effects of different tannery sludge doses on the management of $H$. glycines in soybean crops.

\section{Method}

The experiment was conducted in a greenhouse at Goiano Federal Institute-Urutaí Campus, Goiás State, $\left(17^{\circ} 29^{\prime} 10^{\prime \prime} \mathrm{S}\right.$ and $48^{\circ} 12^{\prime} 38^{\prime \prime} \mathrm{W} ; 697 \mathrm{~m}$ asl.). The study followed a completely randomized experimental design (CRD), with four treatments (increasing tannery sludge doses: $0 ; 5 ; 10 ; 20 \mathrm{Mg} \mathrm{ha}^{-1}$ ) and 5 repetitions. The soybean cultivar used in the experiment was BRS Valiosa RR, which is susceptible to the nematode (Embrapa, 2014).

The amount of tannery sludge applied to the soil took into consideration the $\mathrm{N}$ supply provided by the residue, at mineralization rate $30 \%$ (Cetesb, 1999). Treatments supplying $0,5,100$ and $200 \mathrm{~kg}^{-1} \mathrm{~N} \mathrm{ha}^{-1}$ were carried out through the incorporation of the following sludge doses (dry basis) per hectare: $0 \mathrm{Mg} \mathrm{ha}^{-1}$ (no sludge); $5 \mathrm{Mg} \mathrm{ha}^{-1}$ (9.6 $\mathrm{g}$ of sludge per pot); $10 \mathrm{Mg} \mathrm{ha}^{-1}$ (19.2 $\mathrm{g}$ of sludge per pot); and $20 \mathrm{Mg} \mathrm{ha}^{-1}$ (38.4 $\mathrm{g}$ of sludge per pot). Table 1 presents the chemical analysis applied to the tannery sludge and to the soil used in the experiment.

Table 1. Main characteristics of the soil samples (Haplic Plinthosol) and tannery sludge used in the substrate composition for soybean (Glycines max) cultivation

\begin{tabular}{|c|c|c|}
\hline Attributes & Soil & Tannery sludge \\
\hline $\mathrm{pH}\left(\mathrm{H}_{2} \mathrm{O}\right)$ & 6.28 & - \\
\hline $\mathrm{N}\left(\mathrm{g} \mathrm{dm}^{-3}\right)$ & -1 & 7.47 \\
\hline $\mathrm{P}\left(\mathrm{mg} \mathrm{dm} \mathrm{m}^{-3}\right)$ & 9.55 & 7.90 \\
\hline $\mathrm{K}\left(\mathrm{mg} \mathrm{dm}^{-3}\right)$ & 10.10 & 139.1 \\
\hline $\mathrm{Ca}\left(\mathrm{cmolc} \mathrm{dm}^{-3}\right)$ & 1.09 & 0.00 \\
\hline $\operatorname{Mg}\left(\mathrm{cmolc} \mathrm{dm}^{-3}\right)$ & 0.55 & 9.67 \\
\hline $\mathrm{Na}\left(\mathrm{g} \mathrm{dm}^{-3}\right)$ & - & 12.50 \\
\hline $\mathrm{Cu}\left(\mathrm{mg} \mathrm{dm}^{-3}\right)$ & 4.90 & 1.50 \\
\hline $\mathrm{Fe}\left(\mathrm{mg} \mathrm{dm}^{-3}\right)$ & 337.30 & 5.251 .21 \\
\hline $\operatorname{Mn}\left(\mathrm{mg} \cdot \mathrm{dm}^{-3}\right)$ & 128.10 & 12.05 \\
\hline $\mathrm{Zn}\left(\mathrm{mg} \mathrm{dm} \mathrm{m}^{-3}\right)$ & 8.70 & 89.50 \\
\hline Organic matter (\%) & 0.20 & 44.36 \\
\hline Clay (\%) & 20.00 & - \\
\hline Silt (\%) & 40.60 & - \\
\hline Sand (\%) & 39.40 & 0.00 \\
\hline $\mathrm{Cr}\left(\mathrm{mg} \mathrm{dm}^{-3}\right)$ & 0.00 & 0.00 \\
\hline CTC $\left(\mathrm{cmolc}^{-3} \mathrm{dm}^{-3}\right)$ & 2.57 & - \\
\hline
\end{tabular}

Note. ${ }^{1}(-)$ : non-assessed attribute; CTC: Cation exchange capacity.

The inoculum of the nematode $H$. glycines (race 6) was obtained from a naturally infested area in Ipameri County-GO and subsequently multiplied in ceramic pots, in the root systems of the BRS Valiosa RR soybean cultivar, under greenhouse condition, for 30 days. Next, the plant root systems were subjected to extraction 
process, according to the methodology by Tihohod (2000), in order to obtain the suspension of eggs and second-stage juveniles $(\mathrm{J} 2)$ of the nematode to be used in the experiment inoculation.

Five (5) soybean seeds were sown per ceramic pot (1.4 L capacity) containing substrate composed of soil + sand, at the ratio 1: 1; the pots were previously sterilized with phosphine. The tannery sludge was mixed to the substrate at the time to fill the pots, before the soybean sowing procedure. The pots were kept in the greenhouse and thinning was performed ten days after sowing; a single seedling was kept in each pot in order to compose the experimental unit.

Inoculation was carried out 15 days after sowing, when plants were approximately $10 \mathrm{~cm}$ tall. A suspension containing 2,500 eggs $+\mathrm{J} 2$ of $H$. glycines per seedling was added to the pots, according to the methodology by Dias-Arieira (2003).

The nematode penetration rate was assessed 10 DAI. In order to do so, 5 plants were collected from each treatment and taken to the laboratory. The shoots of these plants were discarded and the root systems were stained according to the plant-tissue nematode staining technique (Byrd et al., 1983). Next, root fragments were placed in glycerin and stored in a refrigerator until the slides were mounted. All the root fragments were placed in Petri dishes and taken to a stereoscopic microscope for J2 quantification ( $15 \times$ magnification).

The root fresh mass, the number of females per root system, and the number of eggs per female in the other plants were assessed 30 DAI. The root systems were subjected to strong water jet under a set of 20-mesh and 60-mesh sieves (Tihohod, 2000). After the washing procedure was over, the material retained in the 20-mesh sieve was discarded, whereas that retained in the 60-mesh sieve was placed in a beaker, with the aid of a wash bottle, and poured onto filter paper placed over a tiled chute (Andrade et al., 1995). Next, the filter paper was placed under a glass plate and analyzed in the stereomicroscope, at 15x magnification, in order to count the number of females.

Subsequently, 10 females from each sample were randomly separated and their bodies were severed in 100-mesh and 400-mesh sieves, with the aid of a rod. The content retained in the 400-mesh sieve, which contained nematode eggs, was collected in a 50-ml beaker and stored in the refrigerator until the end of the counting procedure. The suspension was homogenized and the eggs (1 mL aliquot) were quantified under optical microscope (50× magnification), with the aid of Barlow lens.

Data were subjected to analysis of variance and the means were compared through Tukey test at 5\% probability level. Regression analysis was performed whenever significant differences were found between tannery sludge concentrations. All the data were transformed into square root of $\mathrm{x}+1$ to allow performing the analyses. The SISVAR software version 5.4 was used in the statistical analyses (Ferreira, 2000).

\section{Results and Discussion}

The tannery sludge doses used in the experiment at $5 \%$ probability level significantly influenced the number of second-stage juveniles (J2) per root system, the fresh root mass and the number of females per root gram (Figure $1 \mathrm{~A}, \mathrm{~B}, \mathrm{C})$. 

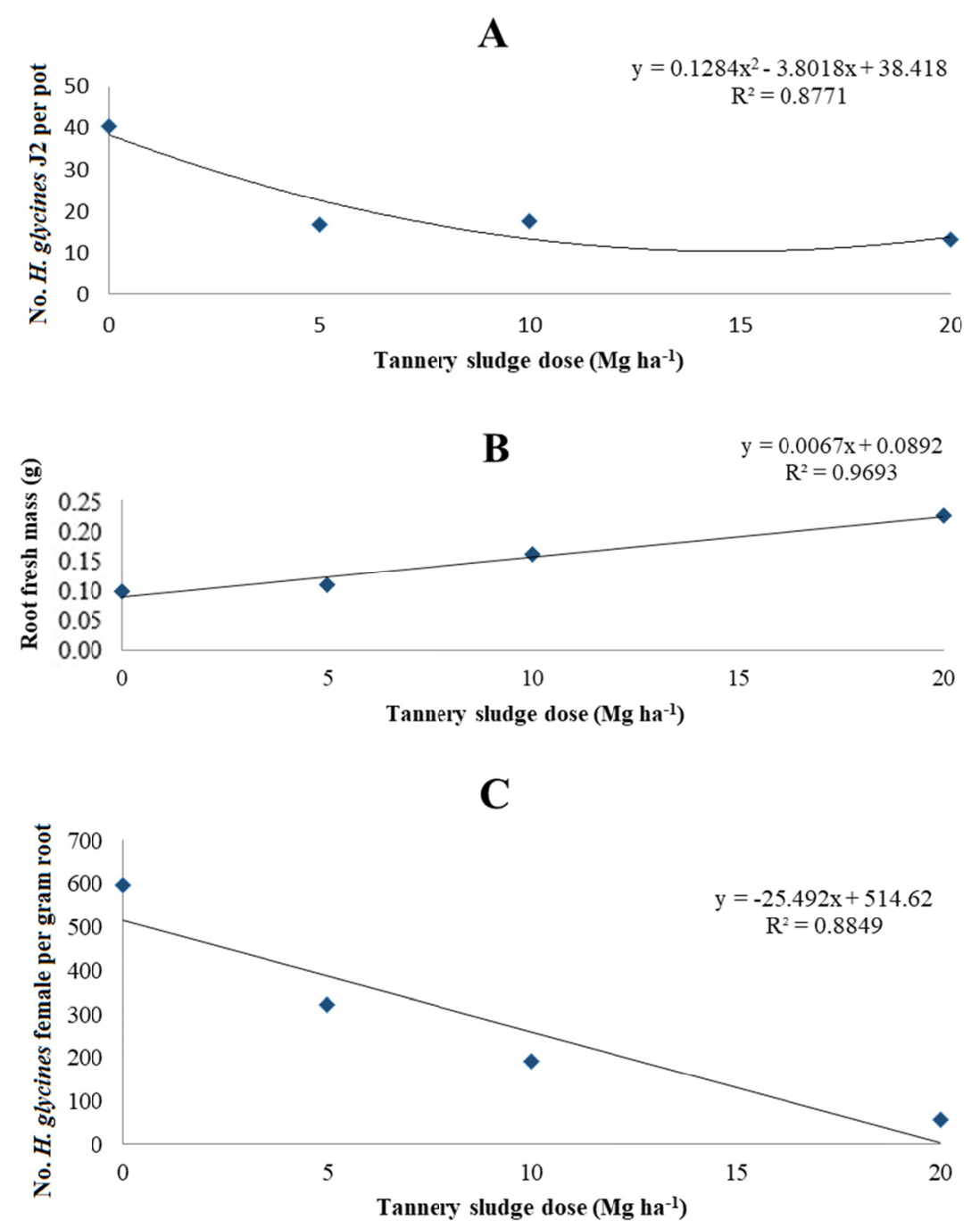

Figure 1. Influence of different tannery sludge doses on the number of second-stage $H$. glycines juveniles (J2) per root system (A), soybean root fresh mass (B) and the number of female H. glycines per root gram (C)

The number of second-stage $H$. glycines juveniles (J2) per root system was assessed 10 DAI; it showed quadratic behavior in the adjustment of the sludge dose effects (Figure 1A), significant correlation with tannery sludge doses, as well as trend to reduce the NCS (in the root systems) whenever the tannery sludge dose incorporated in the soil increased. According to Oka (2010) and Ferraz et al. (2010), the organic fertilizer decomposition process releases compounds such as ammonium and fatty acids, which show nematicide action. These compounds negatively affect phytonematode populations (Oka, 2010), fact that may have reduced the number of J2 nematodes per root system in the current study. Another hypothesis for such reduction lies on the fact that the tannery sludge is a carbon-rich compound that helps controlling plant diseases caused by soil pathogens through the activation of the soil microbiota, which is responsible for performing the biocontrol (Bettiol \& Santos, 2008).

The root fresh mass was assessed 30 days after the inoculation of the BRS Valiosa RR soybean cultivar and showed linear increase as the tannery sludge doses increased (Figure 1B). These results indicated that the tannery sludge enabled higher soybean root system development, since it is nutrient-rich (Table 1); therefore, it increased the crop tolerance to nematode attack. According to Ferreira et al. (2003), tannery sludge can be recommended for soil application since the corrective actions and the fertilizing value of the residue improve nutrient supply; consequently, they improve plant growth.

The literature records several studies showing satisfactory results concerning tannery sludge application to the soil; these studies enable developing better crops, as well as they enable nutrient supply and/or absorption. In this regards, Costa et al. (2001) reported that dry matter and yield increase due to sludge incorporation in the soil. 
According to the aforementioned authors, the application of tannery residues enabled higher soybean dry matter yields than those obtained in the control; in addition, its residual effect was lower than that recorded in the NPK + limestone addition treatment.

Araújo et al. (2008) also assessed maize development and soil fertility in crops subjected to tannery sludge and phosphorite application. The authors found higher maize development in treatments using tannery sludge doses in natura than in those using mineral fertilization; they also noticed that the tannery sludge improved nutrient accumulation and increased phosphorus absorption in plants (treatment using sludge incorporation associated with phosphorite). It is worth highlighting that yields resulting from tannery sludge incorporation in maize-cultivated soils are obtained through immediate organic N release (Konrad \& Castilhos, 2002).

Martines (2009) reported increased maize grain yield due to tannery sludge application to the crop. Maximum grain yield was obtained at the dose $521 \mathrm{~kg} \mathrm{ha}^{-1}$, and it represented $13 \%$ gain in comparison to the control and to the agronomic treatment $\left(120 \mathrm{~kg} \mathrm{ha}^{-1} \mathrm{~N}\right.$ via urea). The aforementioned author also assessed the effect of tannery sludge application on oat crops. The maximum shoot dry matter mass yield was found at the dose $1133 \mathrm{~kg} \mathrm{ha}^{-1} \mathrm{~N}$ via tannery sludge, and it represented $123 \%$ and $75 \%$ yield gain in comparison to the control and to the agronomic treatment (120 $\mathrm{kg} \mathrm{ha}^{-1} \mathrm{~N}$ via urea), respectively.

Santos (2010) found other benefits from sludge application. According to the author, the application of tannery sludge doses led to increased soil fertility and $\mathrm{pH}$ in the assessed Acrisol and Neosol soils; in addition, it increased plant biomass in cowpea beans. Miranda (2014) assessed the effect of composting tannery sludge application (at the doses $0,2.5,5,10$ and $20 \mathrm{Mg} \mathrm{ha}^{-1}$ ) on cowpea beans (Vignia unguiculata (L). Walp) for 4 consecutive years, under field conditions. The author found that the highest cowpea bean yield was found in plants treated with the sludge, more specifically at sludge dose $10 \mathrm{Mg} \mathrm{ha}^{-1}$, and it corresponded to yield increase higher than $29 \%$.

Regarding to the number of female $H$. glycines per root gram, which was also assessed 30 DAI, it showed linear decrease as the tannery sludge doses increased (Figure 1C). This result is directly related to the number of $\mathrm{J} 2$ in the NCS per root system, since its reduction results in a smaller number of nematodes in the root. These results indicate that the presence of tannery sludge in the soil negatively affected nematode development; consequently, it reduced the number of females per root gram. The current results corroborate the study by Renco et al. (2007), who studied the effects of different organic compound sources on the survival and reproduction of Globodera rostochiensis cyst nematodes in potato crops and found that all the tested compounds significantly reduced the number of eggs and juvenile nematodes.

According to Rodriquez-Kabana (1986), the nematicide effect of organic compounds results from the release of toxic substances such as ammonia and nitrites during the decomposition process. Another plausible justification for phytonematode control through organic compounds is that they work as substrate for the growth of nematophagous and nematode cyst-colonizing fungi; these fungi enable biocontrol by significantly reducing the pathogen population (Kerry, 1998). It is worth emphasizing that vermicomposts promote microbial activity by providing resources for the growth of soil bacteria and, mainly, fungi (Edwards, 1998).

In addition, several studies used organic compounds incorporated in cultivated soils and found interesting results in the control of other phytonematodes in different crops. It is worth highlighting the study by Arancon et al. (2002), who reported significant suppression of plant parasitic nematode populations and increased fungi-feeding nematode populations in tomato, pepper, strawberry and grape crops treated with vermicomposts. Vermicompost-based treatments applied to grape and strawberry crops showed phytonematode population reduction and nematophagous fungi population increase, fact that clearly demonstrates that treating soils with vermicomposts significantly helped suppressing nematodes (Arancon et al., 2003). There have been reports that the addition of different organic compound sources to the soil reduced root-knot nematode (Meloidogyne spp.) populations and increased crop yield (Ribeiro et al., 1998; Chen et al., 2000; D’Addabbo et al., 2000).

Conversely, Araújo and Bettiol (2005) assessed the effects of sewage sludge incorporation in the soil on the suppressiveness of root-knot and cyst nematodes; they found that sludge incorporation did not reduce $H$. glycines incidence in soybean roots or affected their development, according to the assessment conducted two months after sowing. Therefore, it is essential conducting further studies in order to assess the effects of sludge on the biology of soybean cyst nematodes. On the other hand, several studies have already found satisfactory results in the control of pathogenic fungi and such control was attributed to the activation of soil microbiota.

Another hypothesis associates nematode reduction with the presence of sludge in the soil. Such hypothesis is supported by the fact that the sludge increases soil pH (Santos, 2010) and that nematodes development is affected by the acidity or alkalinity degree in the environment they live in. The optimum $\mathrm{pH}$ range for nematode 
development between 5.5 and 6.0, as well as $\mathrm{pH}$ near alkalinity, did not favor nematode development (Massaroto \& Yamashita, 2011).

The number of eggs per female nematode was not affected by different tannery sludge doses (Figure 1C). It evidenced that although the incorporation of tannery sludge in the soil reduced the number of females per root gram, it did not affect nematode reproduction, fact that confirmed that the presence of tannery sludge in the soil compromises pathogen survival and development. Similar results were recorded by Sharma et al. (2000), who found that sewage sludge did not affect the cycle of nematodes such as Pratylenchus brachyurus and Helicotylenchus dihystera. On the other hand, Araújo and Bettiol (2005) found that the treatment using sewage sludge at the concentration $20 \mathrm{Mg} \mathrm{ha}^{-1}$ reduced Meloidogyne javanica reproduction in soybean crops.

Araújo and Gentil (2010) also found that increased tannery sludge doses applied to the soil quadratically reduced the reproduction of root-knot nematodes (M. javanica) in soybean roots. According to the aforementioned authors, the effect of the tannery sludge addition to the soil on the reduced reproduction of root-knot nematodes (M. javanica) may be attributed to antagonists that, along with the organic matter in the soil, affected egg hatching and juvenile orientation, as well as parasitized nematode eggs.

The tannery sludge was efficient in the management of $H$. glycines in nematode-susceptible soybean cultivars, since it reduced the number of females per root gram, as well as the number of second-stage nematode juveniles (J2) per root system, and increased root fresh mass. However, it is necessary conducting further studies to help better understanding the nematode reduction dynamics in the presence of organic compounds, since nematode reproduction was not affected by the tannery sludge.

\section{References}

Andrade, P. J. M., Asmus, G. L., \& Silva, J. F. V. (1995). Um novo sistema para deteç̧ão e contagem de cistos de Heterodera glycines recuperados de amostras de solo (pp. 358-358). In Anais do XXVIII Congresso Brasileiro de Fitopatologia. Ilhéus, Brazil.

Arancon, N. Q., Edwards, C. A., Lee, S. S., \& Yardim, E. (2002). Management of plant parasitic nematode populations by use of vermicomposts. Proceedings of the Brighton Crop Protection Conference, 18-21 November, Pests and Diseases (Vol. II, pp. 705-710). Brighton (UK).

Arancon, N. Q., Galvis, P., Edwards, C., \& Yardim, E. (2003). The trophic diversity of nematode communities in soils treated with vermicompost. Pedobiologia, 47, 736-740. https://doi.org/10.1078/0031-4056-00752

Araújo, F. F., \& Bettiol, W. (2005). Supressividade dos nematoides Meloidogyne javanica e Heterodera glycines em soja por adição de lodo de esgoto ao solo. Ciência Rural, 35, 806-812. https://doi.org/10.1590/ S0103-84782005000400009

Araújo, F. F., \& Gentil, G. M. (2010). Ação do lodo de curtume no controle de Meloidogyne spp. e na nodulação em soja. Revista Ceres, 57, 629-632. https://doi.org/10.1590/S0034-737X2010000500010

Araújo, F. F., Tiritan, C. S., \& Pereira, H. M., \& Caetano Júnior, O. (2008). Desenvolvimento do milho e fertilidade do solo após aplicação de lodo de curtume e fosforita. Revista Brasileira de Engenharia Agrícola e Ambiental, 12, 507-511. https://doi.org/10.1590/S1415-43662008000500011

Bettiol, W., \& Santos, I. (2008). Efeito do lodo de esgoto sobre fitopatógeno veiculados pelo solo. Revisão Anual de Patologia de Planta, 16, 233-264.

Byrd, D. W., Kirpatrick, T., \& Barker, K. R. (1983). An improved technique for clearing and staining plant tissue for detection of nematodes. Journal of Nematology, 15, 142-143.

CESTEB. (1999). Aplicação de lodos de curtume em áreas agrícolas - Critérios para projeto e operação. Manual Técnico, Norma P.4.233. Retrieved from http://www.mma.gov.br/port/conama/.../CETESB-NormaP4230 -99-LodoEsgoto.doc

Chen, J., Abawi, G. S., \& Zuckerman, B. M. (2000). Efficacy of Bacillus thuringiensis, Paecilomyces marquandii and Streptomyces costaricanus with and without organic amendment against Meloidogyne hapla infecting lettuce. Journal of Nematology, 32, 70-77.

Costa, C. N., Castilhos, D. D., Castilhos, R. M. V., Konrad, E. E., Passianoto, C., \& Rodrigues, C. G. (2001). Efeito da adição de lodos de curtume sobre as alterações químicas do solo, rendimento de matéria seca e absorção de nutrientes em soja. Revista Brasileira de Agrociência, 7, 189-191.

D'Addabbo, T., Sasanelli, N., Lamberti, F., \& Carella, A. (2000). Control of root knot nematodes by olive and grape pomace soil amendment. In M. L. Gullino, J. Katan, \& A. Matta (Eds.), Proceedings of the fifth 
international symposium on chemical and non chemical soil and substrate disinfestation. Acta Horticulturae (Vol. 523, pp. 53-55).

Dhingra, O. D., Mendonça, H. L., \& Macedo, D. M. (2009). Doenças e seu controle. In T. Sediyama (Ed.), Tecnologias de produção e usos da soja (pp. 133-155). Londrina: Mecenas.

Dias, W. P., Silva, J. F. V., Carneiro, G. E. S., Garcia, A., \& Arias, C. A. A. (2009). Nematoide de cisto da soja: biologia e manejo pelo uso da resistência genética. Nematologia Brasileira, 33, 1-16.

Dias-Arieira, C. R., Ferraz, S., Demuner, A. J., \& Freitas, L. G. (2003). Eclosão de juvenis de Meloidogyne javanica e Heterodera glycines frente a extratos químicos dos sistemas radiculares de Brachiaria brizantha e Panicum maximum cv Guiné. Nematologia Brasileira, 27, 87-92.

Edwards, C. A. (1998). Breakdown of animal, vegetable and industrial organic wastes by earthworms. In C.A. Edwards (Ed.), Earthworm Ecology (pp. 237-354). CRC Press, Boca Raton, Florida.

Empresa Brasileira de Pesquisa Agropecuária (Embrapa). (2014). Soja BRS Valiosa RR. Retrieved December 10, 2014, from https://www.embrapa.br/soja/busca-de-produtos-processos-e-servicos/-/produto-servico/237/ soja---brs-valiosa-rr

Empresa Brasileira de Pesquisa Agropecuária (Embrapa). (2004). Tecnologias de produção de soja-Região Central do Brasil 2004. Retrieved April 16, 2015, from http://www.cnpso.embrapa.br/producaosoja/ doenca.htm

Ferraz, S., Freitas, L. G., LOPES, E. A., \& Dias-Arieira, C. R. (2010). Manejo sustentável de fitonematoides. Viçosa: UFV.

Ferreira, A. S., Camargo, F. A. O., Tedesco, M. J., \& Bissani, C. A. (2003). Alterações de atributos químicos e biológicos de solo e rendimento de milho e soja pela utilização de resíduos de curtume e carbonífero. Revista Brasileira de Ciências do Solo, 27, 755-763. https://doi.org/10.1590/S0100-06832003000400020

Ferreira, D. F. (2000). Análises estatísticas por meio do Sisvar para Windows versão 4.0 (p. 235). In 45 Reunião Anual da Região Brasileira da Sociedade Internacional de Biometria, São Carlos.

Inomoto, M. M. (2006). Principais nematoides na cultura da soja e seu manejo. Piracicaba: ESALQ.

Kerry, B. (1998). Fungal parasites of cysts nematodes. In C. A. Edwards, D. Stinner, \& S. Rabatin (Eds.), Biological Interactions in Soils (pp. 235-249). Elsevier, Amsterdam.

Konrad, E. E., \& Castilhos, D. D. (2002). Alterações químicas do solo e crescimento do milho decorrentes da adição de lodos de curtume. Revista Brasileira de Ciência do Solo, 26, 257-265. https://doi.org/10.1590/ S0100-06832002000100027

Lima, R. D., Ferraz, S., \& Santos, J. M. (1992). Ocorrência de Heterodera sp., em soja no Triângulo Mineiro. Nematologia Brasileira, 16, 101-102.

Lordello, A. I. L., Lordello, R. R. A., \& Quaggio, J. A. (1992). Ocorrência do nematoide de cistos da soja (Heterodera glycines) no Brasil. Revista de Agricultura, 67, 223-225.

Lumsden, R. D., Lewis, J. A., \& Millner, P. D. (1983). Effect of composted sewage ludge on several soilborne pathogens and diseases. Phytopathology, 73, 1543-1548. https://doi.org/10.1094/Phyto-73-1543

Martines, A. M. (2009). Avaliação ambiental e agronômica do uso de lodo de curtume no solo (Tese de doutorado). ESALQ, Brazil.

Massaroto, J. A., \& Yamashita, O. M. (2011). Propriedades do solo relacionadas à inundação para o controle de fitonematoides. Revista de Ciências Agro-Ambientais, 9, 153-163.

Monteiro, A. R., \& Morais, S. R. A. C. (1992). Ocorrência do nematoide de cistos da soja, Heterodera glycines Ichinohe, 1952, prejudicando a cultura no Mato Grosso do Sul. Nematologia Brasileira, 16, 101-102.

$\mathrm{Xu}$, Y., \& Niblack, T. L. (2002). A revised classification scheme for genetically diverse populations of Heterodera glycines. Journal of Nematology, 34, 279-288.

Oka, Y. (2010). Mechanisms of nematode suppression by organic soil amendments: A review. Applied Soil Ecology, 44, 101-115. https://doi.org/10.1016/j.apsoil.2009.11.003

Renco, M., D’Addabbo, T., Sasanelli, N., \& Papajová, I. (2007). The effect of five composto f diferente origin on the survival and reproduction of Globodera rostochiensis. Journal of Nematology, 9, 537-543. https://doi.org/10.1163/156854107781487260 
Ribeiro, C. F., Mizobutsi, E. H., Silva, D. G., Pereira, J. C. R., \& Zambolim, L. (1998). Control of Meloidogyne javanica on lettuce with organic amendments. Fitopatologia Brasileira, 23, 42-44.

Riggs, R. D., \& Schmitt, D. P. (1993) Soybean cyst nematode. In: Sinclair, J. G., \& Barckman, P. A., Compendium of soybean disease, 1993, USA (pp. 65-67). USA: The American Phytopathological Society Press.

Rodriguez-Kabana, R. (1986). Organic and inorganic amendments to soil as nematode suppresants. Journal of Nematology, 18, 129-135.

Santos, J. A. (2010). Compostagem do lodo de curtume e seu uso agrícola: efeito sobre indicadores biológicos de qualidade do solo (Dissertação de Mestrado). Universidade Federal do Piauí, Brazil.

Sharma, R. D., Silva, J. E., Resck, D. V. S., \& Gomes, A. C. (2000). Dinâmica de população de fitonematoides em solo tratado com lodo de esgoto em cultivos de milho. Nematologia Brasileira, 24, 37-40.

Steffen, R. B., Steffen, G. P. K., Antoniolli, Z. I., Jacques, R. J. S., \& Eckhardt, D. P. (2011). Efeito da abamectina e carbofuran no controle de danos causados por M. graminicola em plantas de plantas de arroz irrigado. Revista da FZVA, 18, 56-69.

Tihohod, D. (2000). Nematologia agrícola aplicada. Jaboticabal: FUNEP.

\section{Copyrights}

Copyright for this article is retained by the author(s), with first publication rights granted to the journal.

This is an open-access article distributed under the terms and conditions of the Creative Commons Attribution license (http://creativecommons.org/licenses/by/4.0/). 